\title{
Sedentary Screen Time in Working Adults Before and During COVID-19 Pandemic
}

\author{
COVID-19 Salgını Öncesinde ve Sırasında Çalışan Yetişkin Bireylerin Sedanter Ekran \\ Süreleri
}

\author{
${ }^{1}$ Ayda KARACA \\ ${ }^{2}$ Sinem HAZIR AYTAR \\ ${ }^{1}$ Necip DEMİRCI \\ ${ }^{2}$ Funda AKCAN \\ ${ }^{3}$ Emine Çağlar \\ ${ }^{1}$ Şule Nehir ARAÇ
}

${ }^{1}$ Hacettepe University, Faculty of Sport Sciences, Department of Recreation, Ankara, Turkey

${ }^{2}$ Baskent University, Faculty of Health Sciences, Department of Sport Sciences, Ankara, Turkey

${ }^{3}$ Hacettepe University, Faculty of Sport Sciences, Department of Physical Education and Sports Teaching, Ankara, Turkey

\section{Yazışma Adresi}

Corresponding Address:

Ayda Karaca, $(\mathrm{PhD})$, Associate Professor

ORCID No: 0000-0002-3189-2385

Hacettepe University Faculty of Sport Sciences, Department of Recreation, Division of Physical Activity and Health

E-posta: ayda@hacettepe.edu.tr

\section{ABSTRACT}

The aim of this study was to examine the sedentary screen time (SST) of working individuals before and during the COVID-19 pandemic. Two hundred eighty-nine female and 313 male, a total of 602 (aged between 18-64 years) working adults participated in this study. In order to calculate the duration of sedentary behavior (SB) at work and home, participants were asked to complete the work and household indexes of the Physical Activity Assessment Questionnaire (PAAQ) for Turkish people developed by Karaca et al. (2000). The results of statistical analyses indicated that recreational sedentary screen time (recreational SST) during COVID-19 was higher than before COVID-19 in both genders, in all age groups and all income groups $(p<0.05)$. Sedentary screen time at work during COVID-19 was lower than before COVID-19 in both genders aged between 45-64 of moderate and high income groups $(p<0.05)$. There were no significant differences between before and during COVID-19 in work-related SST at home at all income levels ( $p>0.05$ ). As a result, it was concluded that the SST in the workplace during COVID-19 decreased by about two hours per week, while recreational SST increased by about 10 hours per week compared to the period before COVID-19.

Keywords: Sedentary screen time, Working adults, COVID-19

\section{öz}

Bu çalışmanın amacı, çalışan bireylerin COVID-19 pandemisi öncesinde ve sırasında sedanter olarak geçirdikleri ekran sürelerinin incelenmesidir. Çalışmaya 18-64 yaşları arasında olan 289 kadın ve 313 erkek olmak üzere toplam 602 çalışan birey katılmıştır. İşyerinde ve evde harcanan sedanter sürenin hesaplanabilmesi için katılımcılardan Karaca ve diğ., (2000) tarafından geliştirilen Fiziksel Aktivite Değerlendirme Anketi'nin (FADA) iş ve ev işleri indekslerini doldurmaları istenmiştir. Her iki cinsiyette, tüm yaş gruplarında ve tüm gelir gruplarında COVID-19 sırasındaki rekreasyonel sedanter ekran süresi, COVID-19 öncesinden daha yüksektir ( $p<0.05$ ). Her iki cinsiyette, $45-$ 64 yaş grubunda, orta ve yüksek gelir düzeyinde COVID-19 sırasındaki işyerindeki ekran süresinin, COVID-19 öncesinden daha düşüktür ( $p<0.05)$. Evde iş ile ilgili sedanter ekran süresinde COVID-19 öncesi ve sırası arasında istatistiksel olarak anlamlı fark bulunmamıştır ( $p>0.05$ ). Sonuç olarak; COVID19 öncesi döneme göre COVID-19 sırasında işyerindeki ekran süresinin haftada yaklaşık iki saat azaldığı, rekreasyonel sedanter ekran süresinin ise haftada yaklaşık 10 saat arttığı sonucuna varılmıştır.

Anahtar Kelimeler: Sedanter ekran süresi, Çalışan bireyler, COVID-19 


\section{INTRODUCTION}

On 31 December 2019, Wuhan Municipal Health Commission, China, reported a cluster of cases of pneumonia in Wuhan, Hubei Province. A novel coronavirus (COVID-19) was eventually identified. After 70 days, on 11 March 2020, WHO declared COVID-19 as a pandemic (World Health Organization [WHO], 2020a). According to the data of the World Health Organization, 124,101 cases were confirmed globally on March 11, 2020 (WHO, 2020c). In Turkey, the first case was confirmed on March 11, 2020; a total of 47 cases were confirmed on March 17, 2020 and a total of 98.674 cases were confirmed on April 23, 2020 (WHO, 2020d).

Arrangements were made at international and national levels to take measures for reducing the impact of the COVID19 pandemic in many areas such as social, economic and health. Comprehensive policies of social distance and isolation have been adopted around the world to prevent the spread of the pandemic and reduce the rate of infection in groups prone to high risk of death (Pinto et al., 2020). Similarly, many arrangements were made and measures were taken in Turkey. The importance of these measures, such as following social distance rules and staying at home, was highlighted in videos prepared by the Turkish Ministry of Health (Republic of Turkey Ministry of Health, 2020a). On the other hand, the short-time working application has been launched for the employees in Turkey (Turkish Employment Agency, 2020). Places such as parks, recreation areas, gyms, shopping malls, which were thought to increase the risk of disease transmission due to the close proximity of individuals, were temporarily closed in each province as of 16.03.2020 at 24:00 in accordance with the circular letter published by the Ministry of Interior (Republic of Turkey Ministry of Interior, 2020). Together with these new regulations that have come into force in order to undergo a rapid adaptation process for getting over the COVID-19 pandemic process with less damage, government agencies and many private companies have started to work from home (Turkish Employment Agency, 2020). On the other hand, 187 universities have begun to distance education since April 6, 2020, and 90.1\% of the courses in the spring term are offered in distance education (Council of Higher Education, 2020).

Pinto et al. (2020) stated that physical inactivity may increase because of the need for humans to isolate and quarantine themselves due to fear of being infected in the COVID-19 pandemic. Limiting the lives of individuals to their domestic spaces with the adoption and implementation of the protection and prevention policies mentioned above suggests that the lifestyles of these individuals during COVID 19, including their physical activity habits, may have changed and their recreational SST, one of the indicators of sedentary behavior, may have increased due to physical inactivity compared to the period before COVID-19. For example, the study of Sadarangani et al. (2021) showed that screen time during COVID19 lockdown was more than before COVID-19 lockdown in adults from Argentina and Chile (258.0 min/day, 470,4 $\mathrm{min} / \mathrm{day}$, respectively). Janssen et al. (2020) revealed that sitting time was higher during the first national lockdown than before the lockdown in Scotland. Also, Ünlü et al. (2020) found that the sitting time of adults was higher during COVID19 than before COVID-19 (341.49 $\pm 494.45 \mathrm{~min} /$ week, 257,88 $\pm 261.57 \mathrm{~min} /$ week, respectively).

Sedentary behavior is any waking behavior characterized by an energy expenditure $\leq 1.5$ metabolic equivalents (METs), while in a sitting, reclining or lying posture. Screen time, one of the terms associated with sedentary behavior, includes recreational screen time, stationary screen time, sedentary screen time, and active screen time. Recreational screen time refers to the time spent in screen behaviors that are not related to school or work. These behaviors can be performed while being sedentary or physically active. Sedentary (or stationary) screen time refers to time spent using a screen-based device (e.g., smart phone, tablet, computer, television) while being sedentary in any context (e.g., school, work, recreational) (Sedentary Behavior Reseach Network [SBRN], 2020; Tremblay et al., 2017). 
It has been emphasized that reducing sedentary behavior and recreational screen time plays an important role in prevention of certain chronic diseases (Stamatakis and Hamer, 2011). With increased inactivity, the risk of noncommunicable diseases (NCDs) such as cardiovascular diseases, stroke, diabetes, cancer, osteoporosis, depression increases. It has been noted that mortality increases in COVID-19 patients with these diseases (Lippi et al., 2020). In Spain, China, and the USA, it has been shown that there is a relationship between the seriousness of COVID-19 and NCDs (Kluge et al., 2020). WHO (2020b) conducted a campaign about being active at home during the COVID-19 pandemic, emphasizing the importance of being active and taking short breaks from sitting for the protection of health. Therefore, during the COVID-19 pandemic, where sedentary lifestyle is likely to increase, it is even more important to reduce recreational SST. All of the practices and regulations that have come into force may have created a perception of the seriousness of the pandemic process, even if it does not directly concern the working individuals (such as the transition of all universities to distance education or the curfew imposed on certain age groups). Therefore, it is thought that the measures taken and the recommendations made during the COVID-19 pandemic process may have led to changes in the behavior and lifestyle of working individuals. Based on this, we planned this study to determine the change in the sedentary behavior of working adults during the COVID-19 pandemic as a result of regulations. Accordingly, the a priori hypothesis was that working adults spent more SST during the COVID-19 pandemic than before the COVID-19 pandemic. Therefore, the aim of this study was to examine the SST of working adults associated with sedentary behavior before and during the COVID-19 pandemic.

\section{METHOD}

Participant: The sample size was calculated using $G^{*}$ power version 3.1.9.4. The minimum required sample size was calculated as 580 to estimate sample size with $\alpha=0.05,95 \%$ power, and 0.15 effect size for paired t-tests. Accordingly, participants were recruited by the convenience sampling method (Etikan et al., 2016). This study included 602 participants, 289 women (mean age: 37.80) and 313 men (mean age: 39.16), who were between the ages of 18 and 64 and who were in the employment before COVID - 19. This study was approved by Başkent University Institutional Review Board (Project no: KA20/155). Also, the research approval was taken from the COVID-19 Scientific Research Platform under the Republic of Turkey Ministry of Health, General Directorate of Health Services (No: 2020-05-05T14 04 17).

Instruments and Procedures: An online questionnaire containing questions about demographic information, physical activity and inactivity was sent to the participants electronically (via e-mail and WhatsApp) and the participants were asked to fill out using their mobile phones, tablets or desktop devices. On the first page of the questionnaire, information was given about the research and they were asked whether they approved to participate in the study. All participants signed an online informed consent form. For those who disapproved, the survey was completed, and those who approved completed the survey in about 15-20 minutes. The questions asked in this study include the periods both before and during COVID-19 pandemic. The process that we consider as COVID-19 sequence in this study is between March 17 and April 23, 2020. Participants were asked to consider these dates while answering the questions. Within this time period places such as parks, recreation areas, gyms, shopping centers, which were thought to increase the risk of disease transmission due to the close proximity of individuals, were closed in all provinces between these dates in line with the circular letter published by the Ministry of Interior (Republic of Turkey Ministry of Interior, 2020). Hence all individuals had to stay at their homes due to the lockdown announcement of the government.

Demographic information sheet: It consists of questions such as age, gender, income status, employment status (before and during the pandemic). In order to determine the income status, the participants were asked the question 
'according to you, which of the following best expresses your income level?' and they were asked to mark one of the options 'low, moderate or high'.

Physical activity assessment questionnaire (PAAQ): PAAQ was developed for Turkish people by Karaca et al. in 2000. PAAQ includes work, commuting, household, and exercise indexes. All indexes except exercise have physical activity, inactivity and sedentary behavior (Karaca et al., 2000). The validity of the total index of PAAQ was $r=.72$ ( $\mathrm{p}<0.001$ ), and the reliability of PAAQ changes according to indexes (between $r=.36$ and $r=.70$ ). In this study, sedentary behavior was calculated for work and household indexes.

Data analysis: Recreational SST was measured as the total amount of time spent watching TV, using the computer or tablet for recreational purpose at home. Physically active recreational screen time and work-related SST was not included for calculation of recreational SST. Sedentary screen time at work covers sedentary work activities performed in the workplace only in front of the screen (using a computer and tablet). Work-related SST at home only covers sedentary work activities performed at home in front of the screen (using a computer and tablet).

Statistical Analysis: Skewness and kurtosis coefficients was used to test the normality of the data (George and Mallery, 2012). It showed that a normal distribution assumption was satisfied for work-related SST at work and recreational SST at home variables. Work-related SST at home variable was not normally distributed and therefore logarithmically transformed before the analyses. After this transformation, this variable also showed a normal distribution. Accordingly, in addition to descriptive statistics, whether there is a statistical difference between SST at work, workrelated SST at home, and recreational SST at home variables comparing before and during COVID-19 was examined via the Paired Samples t Test.

\section{Results}

In both female and male working adults, recreational SST during COVID-19 was higher than before COVID-19 $(\mathrm{p}<0.05)$, but during COVID-19, SST at work was lower than before COVID-19 ( $<<0.05)$. Statistically significant differences were not found in both genders in terms of work-related SST at home before and during COVID-19 (p>0.05).

Regarding the age groups, a statistically significant difference was found in recreational SST in each age group before and during COVID-19 ( $\mathrm{p}<0.05$ ). The participants in all ages had longer recreational SST during COVID-19. It was also found that, in the 45-64 age group, SST at work during COVID-19 was lower than before COVID-19 (p<0.05), while there was no statistically significant difference in SST at work in younger age groups before and during COVID-19 ( $p>0.05$ ). There were no statistically significant differences in between before and during COVID-19 in terms of workrelated SST at home of all age groups $(\mathrm{p}>0.05)$.

It was determined that participants with low income levels had a statistically significantly longer recreational SST during COVID-19 than before COVID-19 ( $\mathrm{p}<0.05$ ). In contrast, there was no statistically significant difference between before and during COVID-19 when participants with low income were evaluated in terms of SST at work and workrelated SST at home ( $>0.05)$. Recreational SST in moderate incomed participants was statistically significantly higher during COVID-19 than before COVID-19 (p<0.05). But SST at work was higher before COVID-19 (p<0.05) in the same income group. In participants with high income levels, recreational SST at home during COVID-19 was statistically significantly higher compared to before COVID-19 ( $\mathrm{p}<0.05)$. SST at work before COVID-19 was higher for participants with high income levels compared to the COVID-19 period $(\mathrm{p}<0.05)$. There were no statistically significant differences in work-related SST at home at all income level before and during COVID-19 (p>0.05). 
Table 1

Shows the Participants' SST at Work, Work-Related SST at Home, and Recreational SST at Home Before and During COVID-19

\begin{tabular}{|c|c|c|c|c|c|c|c|}
\hline \multirow[t]{2}{*}{ Duration (hours/week) } & \multirow[t]{2}{*}{$\mathbf{n}$} & \multicolumn{2}{|c|}{$\begin{array}{c}\text { Before } \\
\text { COVID-19 }\end{array}$} & \multicolumn{2}{|c|}{$\begin{array}{l}\text { During } \\
\text { COVID-19 }\end{array}$} & \multirow[t]{2}{*}{$\mathbf{t}$} & \multirow[t]{2}{*}{$\mathbf{p}$} \\
\hline & & Mean & SD & Mean & SD & & \\
\hline \multicolumn{8}{|l|}{ Gender } \\
\hline \multicolumn{8}{|l|}{ Female } \\
\hline Work-related SST at work & 289 & 14.35 & 16.03 & 12.25 & 14.48 & 2.73 & 0.007 \\
\hline Work-related SST at home & 289 & 15.62 & 17.83 & 17.03 & 18.16 & -1.86 & 0.063 \\
\hline Recreational SST at home & 284 & 13.89 & 13.83 & 25.06 & 20.76 & -10.34 & 0.001 \\
\hline \multicolumn{8}{|l|}{ Female } \\
\hline Work-related SST at work & 313 & 16.48 & 17.00 & 14.52 & 17.07 & 2.68 & 0.008 \\
\hline Work-related SST at home & 313 & 15.96 & 19.57 & 16.85 & 21.14 & 0.34 & 0.730 \\
\hline Recreational SST at home & 305 & 13.73 & 15.51 & 22.73 & 22.30 & -9.30 & 0.001 \\
\hline \multicolumn{8}{|l|}{ Age } \\
\hline \multicolumn{8}{|l|}{ 20-29 years } \\
\hline Work-related SST at work & 149 & 10.36 & 16.40 & 13.90 & 14.34 & 1.003 & 0.32 \\
\hline Work-related SST at home & 149 & 13.48 & 18.34 & 15.71 & 20.03 & -1.65 & 0.099 \\
\hline Recreational SST at home & 146 & 12.78 & 16.90 & 24.97 & 22.92 & -7.49 & 0.001 \\
\hline \multicolumn{8}{|l|}{$30-44$ years } \\
\hline Work-related SST at work & 269 & 16.42 & 16.37 & 14.91 & 16.91 & 1.897 & 0.59 \\
\hline Work-related SST at home & 269 & 17.64 & 20.24 & 19.03 & 20.67 & -1.80 & 0.073 \\
\hline Recreational SST at home & 266 & 13.90 & 14.34 & 24.28 & 21.57 & -9.61 & 0.001 \\
\hline \multicolumn{8}{|l|}{$45-64$ years } \\
\hline Work-related SST at work & 184 & 17.34 & 14.81 & 13.75 & 13.56 & 3.703 & 0.001 \\
\hline Work-related SST at home & 184 & 14.97 & 16.47 & 14.88 & 17.86 & 1.563 & 0.120 \\
\hline Recreational SST at home & 177 & 14.50 & 13.28 & 22.29 & 20.48 & -6.29 & 0.001 \\
\hline \multicolumn{8}{|l|}{$\begin{array}{l}\text { Income level } \\
\text { Low income }\end{array}$} \\
\hline Work-related SST at work & 57 & 7.54 & 12.29 & 6.50 & 12.07 & 0.759 & 0.451 \\
\hline Work-related SST at home & 57 & 14.82 & 22.82 & 16.23 & 25.91 & 0.604 & 0.548 \\
\hline Recreational SST at home & 54 & 12.89 & 16.03 & 23.55 & 25.39 & -3.84 & 0.001 \\
\hline \multicolumn{8}{|l|}{ Moderate income } \\
\hline Work-related SST at work & 427 & 14.77 & 15.78 & 13.01 & 15.48 & 3.085 & 0.002 \\
\hline Work-related SST at home & 427 & 14.08 & 16.84 & 15.78 & 17.99 & -1.85 & 0.064 \\
\hline Recreational SST at home & 419 & 14.23 & 15.12 & 24.09 & 21.18 & -12.06 & 0.001 \\
\hline \multicolumn{8}{|l|}{ High income } \\
\hline Work-related SST at work & 118 & 21.76 & 18.91 & 18.30 & 17.61 & 2.157 & 0.033 \\
\hline Work-related SST at home & 118 & 22.47 & 21.58 & 21.47 & 21.8 & 0.552 & 0.582 \\
\hline Recreational SST at home & 116 & 12.69 & 12.42 & 23.15 & 21.29 & -5.88 & 0.001 \\
\hline \multicolumn{8}{|l|}{ All participants } \\
\hline Work-related SST at work & 602 & 15.46 & 16.56 & 13.43 & 15.91 & 3.833 & 0.001 \\
\hline Work-related SST at home & 602 & 15.80 & 18.74 & 16.94 & 19.76 & -1.18 & 0.239 \\
\hline Recreational SST at home & 589 & 13.81 & 14.71 & 23.86 & 21.59 & -13.89 & 0.001 \\
\hline
\end{tabular}

When the data of all participants $(n=602)$ were examined, it was concluded that SST at work decreased by about two hours per week $(\mathrm{p}<0.001)$ during COVID-19 compared to before COVID-19 period, while recreational SST increased by about 10 hours per week $(\mathrm{p}<0.001)$.

The percentage of recreational SST below 3 hours per day prior to COVID-19 in all groups decreased significantly during COVID-19, while the percentage of recreational SST above 3 hours per day increased significantly. The percentage 
of participants having recreational SST above the recommended level prior to COVID-19 was $21.4 \%$, while during COVID-19 it increased to $44.9 \%$.

Table 2

Recommended Recreational SST ( $\leq 3$ Hours/Day) Before COVID-19 and During COVID-19 in the Working Adults

\begin{tabular}{|c|c|c|c|c|c|c|c|c|}
\hline & \multicolumn{4}{|c|}{$\leq 3$ hours/day } & \multicolumn{4}{|c|}{$>3$ hours/day } \\
\hline & \multicolumn{2}{|c|}{$\begin{array}{c}\text { Before } \\
\text { COVID-19 }\end{array}$} & \multicolumn{2}{|c|}{$\begin{array}{c}\text { During } \\
\text { COVID-19 }\end{array}$} & \multicolumn{2}{|c|}{$\begin{array}{c}\text { Before } \\
\text { COVID-19 }\end{array}$} & \multicolumn{2}{|c|}{$\begin{array}{c}\text { During } \\
\text { COVID-19 }\end{array}$} \\
\hline & $f$ & $\%$ & $f$ & $\%$ & $f$ & $\%$ & $f$ & $\%$ \\
\hline \multicolumn{9}{|l|}{ Gender } \\
\hline Female & 232 & 80.3 & 152 & 52.6 & 56 & 19.40 & 132 & 45.7 \\
\hline Male & 235 & 75.1 & 170 & 54.3 & 73 & 23.3 & 138 & 44.1 \\
\hline \multicolumn{9}{|l|}{ Age } \\
\hline 20-29 years & 117 & 78.5 & 76 & 51.0 & 31 & 20.8 & 71 & 47.7 \\
\hline $30-44$ years & 215 & 79.9 & 147 & 54.6 & 53 & 19.7 & 119 & 44.2 \\
\hline $45-64$ years & 135 & 73.4 & 99 & 53.8 & 45 & 24.5 & 80 & 43.5 \\
\hline \multicolumn{9}{|l|}{ Income level } \\
\hline Low & 43 & 75.4 & 32 & 56.1 & 13 & 22.8 & 23 & 40.40 \\
\hline Moderate & 327 & 76.6 & 223 & 52.2 & 96 & 22.5 & 197 & 46.1 \\
\hline High & 97 & 82.2 & 67 & 56.8 & 20 & 16.9 & 50 & 42.4 \\
\hline All participants & 467 & 77.6 & 322 & 53.5 & 129 & 21.4 & 270 & 44.9 \\
\hline
\end{tabular}

\section{DISCUSSION}

The aim of this study was to examine the work-related and recreational SST spent at work or at home before COVID19 and during COVID-19 in terms of gender, age and income level. SST at work decreased during COVID-19 compared to before COVID-19 in both genders $(\mathrm{p}<0.05)$ while recreational SST increased $(\mathrm{p}<0.05$, Table 1$)$. With the increase of the coronavirus pandemic, feelings such as panic and despair caused by the fear of getting sick may have resulted in more isolated environments and made it more difficult to maintain daily exercise or physical activity routines (Qin et al., 2020). This may explain the increase in recreational SST in both genders during the COVID-19 period. It is claimed that changes in the lifestyle of individuals were observed with the onset of the COVID-19 pandemic (Hu et al., 2020). For example, in a study of $\mathrm{Hu}$ et al. (2020), the percentage of those whose lifestyle changed positively during COVID-19 in terms of the frequency of regular consumption of vegetables and fruits was reported to be more than that of those whose lifestyle changed negatively, however there was a decrease in the level of physical activity and an increase in the time spent in front of the screen. Chen et al., (2020), on the other hand, noted that during the COVID-19 regulations, lifestyle changes are likely to occur due to changes in daily eating patterns, restrictions on physical activity, and an increase in the screen time.

Avoiding excessive screen time and engaging in exercise were important behaviors associated with better perceived mental and general health during the COVID-19 pandemic (Colley et al., 2020). However, studies showed the reverse tendency in terms of screen time and exercise levels. For example, Meyer et al. (2020)'s study showed that individuals who were active before COVID-19 period had an increase in the screen and sitting time due to social isolation, staying at home and social distance during the COVID-19 period, while a decrease in physical activity occurred. However, in inactive individuals, there was an increase in time spent in front of the screen and sitting, while there was no change in physical activity levels (Meyer et al., 2020). Because social and home isolation practices carried out in order to prevent possible crowd of people in public places and indoor spaces may have triggered the increase in the use of technology (video and applications etc.) at home (Górnicka et al., 2020). From this perspective, the increase in recreational SST in 
both genders during the COVID-19 period can be explained by the changing lifestyle. In other words, the increase in time spent at home as a result of the restrictions of "social isolation, staying at home and social distance" during COVID-19 may have brought about an increase in recreational SST in terms of gender, age and income level.

Majumdar et al., (2020) stated that office workers' desktop/laptop usage was lower before COVID-19 than during COVID-19 (6.4 \pm 2.9 hours/day, 8.2 \pm 3.36 hours/day, respectively). Desktop/laptop usage significantly increased as a result of working from home or conducting business activities at home. In addition, measures to be taken at workplaces according to different occupational groups have been reported in the COVID-19 Pandemic Management and Working Guidelines prepared by the Ministry of Health in Turkey (Republic of Turkey Ministry of Health, 2020b). With the guidance provided within the framework of these measures, it is predicted that the implementation of isolation policies that encourage working from home, especially in the period of COVID-19, leads to changes in the working activities of individuals (Republic of Turkey Ministry of Health, 2020b). As a matter of fact, this may explain the significant decrease in the time spent in front of the screen at work during COVID-19 of the male and female participants in our study compared to the period before COVID-19.

When examined according to age groups, only the 45-64 age group had less SST at work during COVID-19 than before COVID-19 ( $<<0.05)$. In terms of work-related SST at home, no difference was found in any of the age groups before COVID-19 and during COVID-19 (Table 1). However, in the study of De Cocker et al., (2014), more occupational sitting was associated with being younger. Burton Haynes et al., (2012) noted that people between the ages of 55 and 64 had relatively higher sitting times on working days due to part-time or short working times. Although this age group had more free time, the longer sitting periods were attributed to the decrease in "perceptions of seeking to be physically active" (Burton et al., 2012). The higher prevalence of insufficient physical activity among those aged 20-34 than those under 20 and over 34 was attributed to the increase in screen time (Qin et al., 2020). Moreover, it was stated that the insufficient physical activity and the time spent in front of the screen in the elderly people of China during the home quarantine process caused by COVID-19 were lower in those aged 55-59 and over 60 (Qin et al., 2020). Similarly, in this study, it was found that recreational SST during COVID-19 was higher in all age categories than before COVID-19 (Table 1). Compared to before the pandemic, recreational SST during the pandemic increased by about 7.5 hours per week in the 45-64 age group, while in other age groups, this increase was over 10 hours per week. In addition, while the average recreational SST of the 45-64 age group before the pandemic was higher than the other groups, it was found lower than the other groups during COVID-19. Previously, it was showed that middle-aged (40-44) individuals' use of computers for work is higher compared to older individuals leads to an increase in work-related computer use at home, including at the weekend (Burton et al., 2012). As a result of restrictions on working time due to the COVID-19 pandemic, both workrelated SST at home and recreational SST might have increased with the decrease in time spent at work and increase in time spent at home. The increase in recreational SST in all age categories might be due to the decreased physical activity, decreased working time, and increased time spent at home.

In the studies conducted by Banks et al., (2011), it was found that the risk of increase in the screen time is higher in those not in employment compared to individuals working full time. From this point of view, as stated in the study of Banks et al, the screen time of those who do not work in a workplace is higher. As stated in this study, during the COVID19 period, the increase in the time spent at home as a result of the decrease in the working time of the employed individuals, as in the individuals who are not in employment, might have led to an increase in the time spent in front of the screen. In this study, it can also be expressed that the reason of increased recreational SST at all income levels during COVID-19 compared to before COVID-19 could be the increase in time spent at home due to social isolation. Both before 
and during COVID-19, SST at work was found in increase as the income levels increased (Table 1). This might be caused by the fact that as participants' income level increases, the job they do requires more time on the screen.

Findings of Saunders et al. (2020)'s meta-analysis study have important public health implications, suggesting that adults should avoid high levels of sedentary behavior and break-up periods of prolonged sitting. Preexisting chronic conditions such as hypertension, cardiovascular disease, and diabetes are strongly associated with an increased risk of developing severe COVID-19 (Wang et al., 2020). Therefore, reducing the duration of sedentary behavior, which is one of the most important risk factors of chronic non-communicable diseases, is of critical importance. In parallel, it is recommended that the daily recreational screen time should not exceed 3 hours (Canadian Society for Exercise Physiology, 2020). In this study, the percentage of the recreational SST of the participants above 3 hours per day before and during COVID-19 was determined. The percentage of participants having more than 3 hours of recreational SST per day increased from $21.4 \%$ before COVID-19 to $44.9 \%$ during COVID-19. It was estimated that the increase in free time due to the factors such as longer stay at home because of part-time work and social isolation, resulted in an increase in recreational sedentary screen activities among participants.

The first limitation of this study is that the sedentary time was not measured with an accelerometer, as an objective method. Second, the findings may be relevant only employees who worked before COVID-19, which limits the generalizability of the results to the whole Turkish adult population. However, assuming that the pandemic is a new and unpredictable situation for many people, this study can be considered to provide important information in terms of the fact that its data reflects the lifestyles of individuals during such a period. The first six weeks covering the data of this study can also be considered a strong aspect of the study in terms of reflecting a specific time, since it also covers the period when there is a lockdown in Turkey. The number of participants is also one of the relative strengths of this study.

To conclude, the present study indicates that during COVID-19, SST in the workplace decreased by about two hours per week compared to the pre-COVID-19 period, while recreational SST increased by about 10 hours per week. This increase in SST may lead to chronic health problems in working adults. Thus, it would be important to take precautions to reduce the amount of time spent in sedentary activities. In future studies, the reasons underlying the increased SST need to be explored in more detail by using a qualitative method. In addition, if COVID-19 continues for a while or if other situations that may require staying home arise; further studies could examine the relationship between sedentary behavior and body composition, and healthy lifestyle behaviors such as exercise, healthy eating. In addition, in light of the data obtained, the focus on developing strategies for reducing sedentary behavior appears to be important in the context of the viability of research results. 


\section{Yazar Katkısı (Author contributions):}

1. Ayda KARACA: Idea/Conceptualization, Design, Supervision, Data collection or Processing, Analysis and Interpretation, Writing, Critical Review

2. Sinem HAZIR AYTAR: Idea/Conceptualization, Design, Supervision, Data collection or Processing, Analysis and Interpretation, Writing

3. Necip DEMİRCI: Idea/Conceptualization, Design, Data collection or Processing, Analysis and Interpretation, Writing

4. Funda AKCAN: Idea/Conceptualization, Design, Data collection or Processing, Writing, Critical Review

5. Emine ÇAĞLAR: Idea/Conceptualization, Design, Data collection or Processing, Writing, Critical Review

6. Nehir Şule ARAÇ: Idea/Conceptualization, Data collection or Processing

Ethical Committee: Baskent University Institutional Review Board

Date: 30.04 .2020

Decision Number: 94603339-604.01.02/13364 


\section{REFERENCES}

1. Banks, E., Jorm, L., Rogers, K., Clements, M., and Bauman, A. (2011). Screen-time, obesity, ageing and disability: Findings from 91 266 participants in the 45 and up study. Public Health Nutrition, 14(1), 34-43. https://doi.org/10.1017/S1368980010000674.

2. Burton, N.W., Haynes, M., Van Uffelen, J.G., Brown, W.J., and Turrell, G. (2012). Mid-aged adults' sitting time in three contexts. American Journal Of Preventive Medicine, 42(4), 363-373. https://doi.org/10.1016/j.amepre.2011.11.012.

3. Canadian Society for Exercise Physiology. (2020). Canadian 24-hour movement guidelines for adults aged 18-64 years: An integration of physical activity, sedentary behaviour, and sleep. Retrieved November 12, 2020, fromhttps://csepguidelines.ca/wpcontent/uploads/2020/10/24HMovementGuidelines-Adults18-64-2020-ENG.pdf

4. Chen, P., Mao, L., Nassis, G.P., Harmer, P., Ainsworth, B.E., and Li, F. (2020). Coronavirus disease (COVID-19): The need to maintain regular physical activity while taking precautions. Journal of Sport and Health Science, 9(2), 103-104. https://doi.org/10.1016/j.jshs.2020.02.001.

5. Colley, R.C., Bushnik, T., and Langlois, K. (2020). Exercise and screen time during the COVID-19 pandemic. Health Rep, 31 (6), 3-11. https://doi.org/10.25318/82-003-x202000600001-eng.

6. Council of Higher Education (CHE) (2020). CoHE releases evaluation of distance education at universities. Retrieved May 31, 2020, from https://www.yok.gov.tr/en/Sayfalar/news/2020/distance-learning-at-universities.aspx

7. De Cocker, K., Duncan, M.J., Short, C., Van Uffelen, J.G., and Vandelanotte, C. (2014). Understanding occupational sitting: prevalence, correlates and moderating effects in Australian employees. Preventive Medicine, 67, 288-294. https://doi.org/10.1016/j.ypmed.2014.07.031.

8. Etikan, I., Musa, S.A., and Alkassim, R.S. (2016). Comparison of convenience sampling and purposive sampling. American Journal of Theoretical and Applied Statistics, 5(1), 1-4. https://doi.org/10.11648/j.ajtas.20160501.11

9. George, D., and Mallery, M. (2010). SPSS for windows step by step: A simple guide and reference, 17.0 update (10a ed.) Boston: Pearson.

10. Górnicka, M., Drywień, M.E., Zielinska, M.A., and Hamułka, J. (2020). Dietary and lifestyle changes during COVID-19 and the subsequent lockdowns among Polish adults: A Cross-sectional online survey PLifeCOVID-19 study. Nutrients, 12(8), 1-20. https://doi.org/10.3390/nu12082324.

11. Hu, Z., Lin, X., and Xu, H. (2020). The impact of coronavirus disease (COVID-19) epidemic on lifestyle behaviors and their association with subjective wellbeing among the general population in the Mainland China: A cross-sectional study. Journal of Medical Internet Research, 22(8), 1-10. https://doi.org/10.2196/21176.

12. Janssen, X., Fleming, L., Kirk, A., Rollins, L., Young, D., Grealy, M., MacDonald, B., Flowers, P., and Williams, L. (2020). Changes in physical activity, sitting and sleep across the COVID-19 national lockdown period in Scotland. International Journal of Environmental Research and Public Health, 17(24), 9362. https://doi.org/10.3390/ijerph17249362

13. Karaca, A., Ergen, E., and Koruç, Z. (2000). The reliability and the validity of the physical activity assessment questionnaire (PAAQ). Hacettepe Journal of Sport Sciences, 11(1), 17-28.

14. Kluge, H.H.P., Wickramasinghe, K., Rippin, H.L., Mendes, R., Peters, D.H., Kontsevaya, A., and Breda, J. (2020). Prevention and control of non-communicable diseases in the COVID-19 response. The Lancet, 395(10238), 1678-1680. https://doi.org/10.1016/S0140-6736(20)310679

15. Lippi, G., Henry, B.M., and Sanchis-Gomar, F. (2020). Physical inactivity and cardiovascular disease at the time of coronavirus disease 2019 (COVID-19). European Journal of Preventive Cardiology, 27(9), 906-908. https://doi.org/10.1177/2047487320916823.

16. Majumdar, P., Biswas, A., and Sahu, S. (2020). COVID-19 pandemic and lockdown: Cause of sleep disruption, depression, somatic pain, and increased screen exposure of office workers and students of India. Chronobiology International, 37(8), 1191-1200. https://doi.org/10.1080/07420528.2020.1786107.

17. Meyer, J., McDowell, C., Lansing, J., Brower, C., Smith, L., Tully, M.A., and Herring, M. (2020). Changes in physical activity and sedentary behavior in response to COVID-19 and their associations with mental health in 3,052 US adults. International Journal of Environmental Research and Public Health, 17(18), 1-13. https://doi.org/10.3390/ijerph17186469.

18. Pinto, A.J., Dunstan, D.W., Owen, N., Bonfá, E., and Gualano, B. (2020). Combating physical inactivity during the COVID-19 pandemic. Nature Reviews Rheumatology, 16(7), 1-2. https://doi.org/10.1038/s41584-020-0427-z. 
19. Qin, F., Song, Y., Nassis, G.P., Zhao, L., Cui, S., Lai, L., Wu, Z., Xu, M., Qu, C., Dong, Y., Wang, Z., Geng, X., Zhao, C., Feng, Y., Han, Z., Fan, Z., and Zhao, J. (2020). Prevalence of insufficient physical activity, sedentary screen time and emotional well-being during the early days of the 2019 novel coronavirus (COVID-19) outbreak in China: A national cross-sectional study. The Lancet, 17(14), 1-16. https://doi.org/10.3390/ijerph17145170.

20. Republic of Turkey Ministry of Interior. (2020). An additional circular on coronavirus measures sent to 81 provincial governorships. Retrieved June 4, 2020, from https://www.icisleri.gov.tr/81-il-valiligine-koronavirus-tedbirleri-konulu-ek-genelge-gonderildi

21. Republic of Turkey Ministry of Health. (2020a). COVID-19 new coronavirus disease: COVID-19 videos. Retrieved May 31, 2020, from https://covid19bilgi.saglik.gov.tr/tr/videolar.

22. Republic of Turkey Ministry of Health. (2020b). COVID-19 outbreak management and labour guide. Retrieved October 1, 2020, from https://covid19.saglik.gov.tr/Eklenti/39265/0/covid-19salginyonetimivecalismarehberipdf.pdf

23. Sadarangani, K.P., De Roia, G.F., Lobo, P., Chavez, R., Meyer, J., Cristi-Montero, C., Martine-Gomez, D., Ferrari, G., Schuch, F.B., Gil-Salmeron, A., Solmi, M., Veronese, N., Alzahrani, H., Grabovac, I., Caperchione, C.M., Tully, MA., and Smith L. (2021). Changes in sitting time, screen exposure and physical activity during Covid-19 lockdown in South American adults: A cross-sectional study. International Journal of Environmental Research and Public Health, 18(10), 5239. https://doi.org/10.3390/ijerph18105239

24. Saunders, T.J., McIsaac, T., Douillette, K., Gaulton, N., Hunter, S., Rhodes, R.E., Prince, S.A., Carson, V., Chaput, J.P., Chastin, S., Giangregorio, L., Janssen, I., Katzmarzyk, P.T., Kho, M.E., Poitras, V.J., Powell, K.E., Ross, R., Ross-White, A., Tremblay, M.S., and Healy, G.N. (2020). Sedentary behaviour and health in adults: an overview of systematic reviews. Applied Physiology, Nutrition, and Metabolism, 45(10), 197-217. https://doi.org/10.1139/apnm-2020-0272.

25. Sedentary Behavior Reseach Network (SBRN) (2020). Consensus definitions. Retrieved October 11, 2020, from https://www.sedentarybehaviour.org/sbrn-terminology-consensus-project/\#consensus-definitions

26. Stamatakis, E., and Hamer, M. (2011). Sedentary behaviour: Redefining its meaning and links to chronic disease. British Journal of Hospital Medicine, 72(4), 192-195. https://doi.org/10.12968/hmed.2011.72.4.192.

27. Tremblay, M.S., Aubert, S., Barnes, J.D., Saunders, T.J., Carson, V., Latimer-Cheung, A.E., Chastin, S.F.M., Altenburg, T.M., and Chinapaw, M.J.M. (2017). Sedentary behavior research network (SBRN)-terminology consensus project process and outcome. International Journal of Behavioral Nutrition and Physical Activity, 14(1), 1-17. https://doi.org/10.1186/s12966-017-0525-8.

28. Turkish Employment Agency. (2020). Short-term employment allowance: Making an effective short study request and evaluation of the new type of coronavirus (Covid-19). Retrieved May 31, 2020 from https://www.iskur.gov.tr/isveren/kisa-calisma-odenegi/genel-bilgiler/

29. Ünlü, H., Öztürk, B., Aktaş, Ö., and Büyüktaş, B. (2020). Investigation of change in physical activity levels of individuals during COVID-19 process. Turkish Journal of Sports Science, 4(2), 79-87. https://doi.org/10.32706/tusbid.803497

30. Wang, X., Fang, X., Cai, Z., Wu, X,. Gao, X., Min, J., and Wang, F. (2020). Comorbid chronic diseases and acute organ injuries are strongly correlated with disease severity and mortality among COVID-19 patients: A systemic review and meta-analysis. Research, 2020(2402961), 115. https://doi.org/10.34133/2020/2402961.

31. World Health Organization. (2020a). Archived: WHO timeline - COVID-19. Retrieved May 31, 2020, from https://www.who.int/newsroom/detail/27-04-2020-who-timeline---covid-19

32. World Health Organization. (2020b). \#HealthyAtHome - Physical activity. Retrieved June 7, 2020, from https://www.who.int/newsroom/campaigns/connecting-the-world-to-combatcoronavirus/healthyathome/healthyathome---physical-activity

33. World Health Organization. (2020c). WHO coronavirus disease (COVID-19) dashboard. Retrieved May 30, 2020, from https://covid19.who.int/

34. World Health Organization. (2020d). WHO coronavirus disease (COVID-19) dashboard: Turkey. Retrieved May 30, 2020, from https://covid19.who.int/region/euro/country/tr 